\title{
OBSERVATION OF ROYLE'S PIKA (OCHOTONA ROYLEI) IN API NAMPA CONSERVATION AREA, FAR WESTERN REGION, NEPAL
}

\author{
N.P. Koju ${ }^{1}$ and M.K. Chalise ${ }^{2}$
}

\section{ABSTRACT}

This study was carried out on the southern base of Mt. Api in Api Nampa Conservation Area (ANCA) during June of 2012 and 2013. Pikas were observed for their population and behaviors. Feeding behavior was observed on more than 23 plants species including poisonous species to cattle. Pikas raid the human supply sometime peeping into human shelter. Local people use pika meat to cure some diseases.

Key words: pika population, habitat, medicinal use, far west Nepal

\section{INTRODUCTION}

Pikas are small mammals weighing about 100-150 gram (Smith and Xie 2008), having rounded ears, short legs and devoid of tails. They have little longer front legs than the rear ones. Pikas are absolutely endemic to the Himalayas, the mountains and steppes of central Asia, and the mountains of north-western America (Prater 2005). They are having four incisors which make them differ from rodents having two incisors. Pikas are unique among the alpine mammals in that they gather up vegetation throughout summer including flowers, grasses, leaves, evergreen needles, and even pine cones and live off the hay pile throughout winter, rather than hibernating or moving down slope (Holtcamp 2010). Pika's burrows are interestingly shared by other faunal component mainly small mammals and birds. Their burrows offer breeding habitat for birds like Hume's Ground Jay (Psudopodoces humilis), Scaly-breasted Wren-babbler (Pnoepyge albiventer) and Snowfinch (Pyrgiauda davidiana). Thus, Pika is keystone species for conservation of biodiversity of Himalayan region (Khanal 2007). Various evidences have shown a good relation of livestock to Pika's hay-piles. Shrews (Sorex sp.) hunt Pika's hay-piles in alpine region to feed upon insects present inside (Naumov 1974). Hay-piles provide shelter to birds, lizards and insects and also help to increase plant diversity around the vicinity of the hay pile areas (Primack 1998).

Royle's Pika is a common species throughout the Himalayan region (Hoffmann and Smith 2005). Their body length ranges from 15 to $20 \mathrm{~cm}$ and the diameter of head is $7 \mathrm{~cm}$ (Alfred et al. 2006). Their distribution is governed directly on the basis of availability of forage plant species (Kawamichi 1968). The Royle's Pika (Ochotona roylei) is characteristically associated with broken slopes and piles of boulders. This species generally lives at lower elevations than the Large-eared Pika (Ochotona macrotis) when they are sympatric (Smith 1974). Royle's Pika may inhabit the rock wall huts of local people throughout its range (Kawamichi 1968, 1971, Abe 1971) from Pakistan to Kashmir, north-western India, Nepal, and Tibet (Smith et 
al.1990). In Nepal it is reported from Langtang National Park, Makalu Barun National Park Rara National Park, Sagarmatha National Park, Khaptad National Park, Annapurna Conservation Area, Manasulu Conservation Area, and Kanchanjangha Conservation Area (Shrestha 1997, Koju et al. 2011). There are two recognized subspecies: Ochotona roylei nepalensis and $O$. r. roylei (Hoffmann and Smith 2005). Sherpa community of Langtang Nepal named it locally as 'Bhragomjin' to Pika and respects it as Buddhist monk (Koju et al. 2013) while Pika in Api Nampa is locally known as 'Hundra' (Koju and Chalise 2012) and some of them also call it as "Khar Musa" or Phyau Musa.

During summer the head, shoulders and fore part of the body are bright chestnut colored, becoming darker on the throat. The remainder of the dorsal surface is dark grayish rufous. Ventral part of its body fur consists of the coloration which ranges from white to grayish white to dark gray (Smith et al. 1990). The density of royle's pika was 12.5 animal/ha (Kawamichi 1968). Koju et al. (2012) recorded 14 individuals per hectare with adult and juvenile ratio 16:33 in Langtang National Park. There were no sign like burrow with pellets of Pika, pugmark and no sign of individual below $3098 \mathrm{~m}$ in Api Nampa. Active burrow were observed from $3263 \mathrm{~m}$ amsl and Pikas were noticed from 3738m amsl (Koju and Chalise 2012). Annually thousands of people visit to Api Nampa area for the collection of Yarchagumba (Cordyceps sinesis) and other herbs. They pass through the habitats of Pika and some people also live (temporary huts) in their habitat (Koju and Chalise 2013).

\section{STUDY AREA}

Api Nampa Conservation Area (ANCA) established in the year of 2010 to conserve the natural beauty and ecosystem of the far west Nepal at the northernmost frontier adjoining India at west and China to the north. The conservation area occupies 1903 square kilometers covering 21 Village Development Committees (VDCs) of Darchula district, far west-north of Nepal. The conservation area is named behind the Mount Api (7132 m) and Nampa (6757 m) which lie within the area. The conservation area includes different vegetation type, the central core area is plateau of grasslands intermixed with oak, coniferous forest, riverine deciduous temperate forest (DNPWC 2013). Diverse climatic condition and altitudinal variation of the area provided habitats for many rare, endangered and threatened wildlife species including the Snow leopard, Musk deer, Thar and Clouded leopard (Chalise 2012). Birds include the national bird of Nepal, Danphe or Himalayan Monal (Lophophorus impejanus) and Satyr Tragopan (Tragopan satyra).

The study was carried on June, 2012 and June 2013. The exploration of Pika was done from Simar (N 2953'33.4" E 8056'00.7" elevation $2846 \mathrm{~m}$ asl) to Loal (N 2958'15.0" E 8056'06.7" elevation $3874 \mathrm{~m}$ asl). Loal is three days walk from the Bitule bus stop while one day walks from the Khaikot, Ghusa VDC, the last human settlement on the way to Mt. Api and trail passage along with the Chaulane (Chameliya) river (fig. 1). 


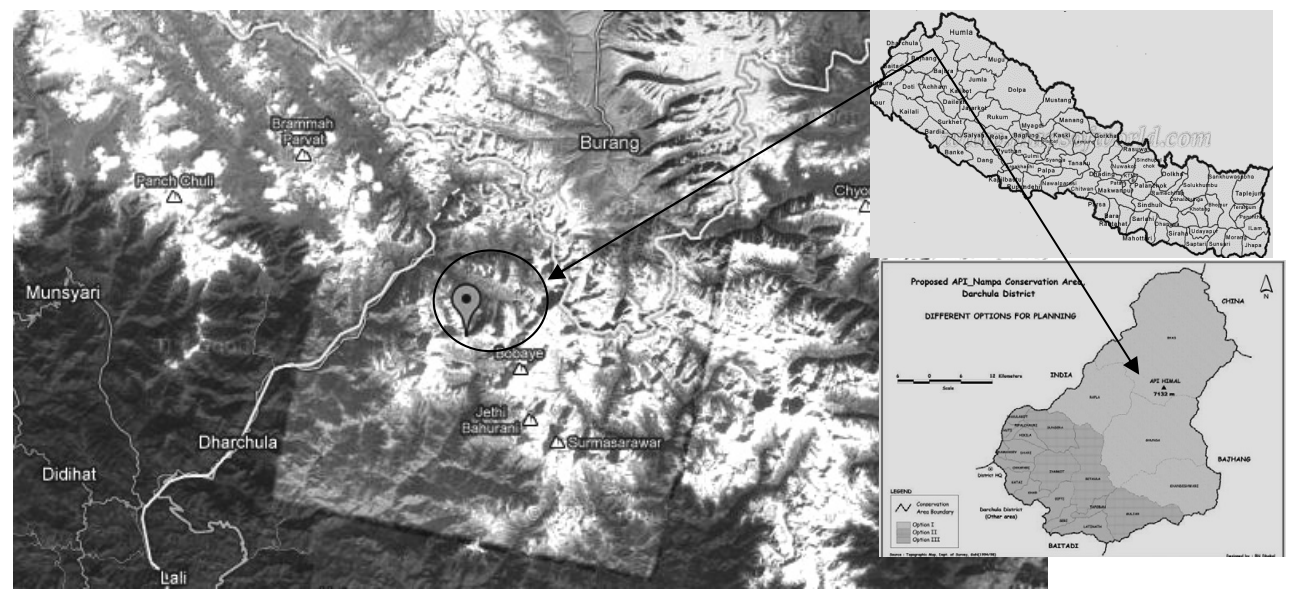

Figure 1. Map showing study site in Api Nampa conservation area in Nepal.

\section{MATERIALS AND METHODS}

Questionnaire/ interviews were performed with local people, local sheep/goat herders and Yarcha gumba (Cordyceps sinensis) collectors to explore the habitats of Pika and its socioeconomic importance. $50 \mathrm{~m} \times 50 \mathrm{~m}$ quadrate was randomly plotted from 'Simar' (2846 m asl) to base of Api Nampa (3874 m asl) to explore the habitat of pika and to estimate its population density. Scan sampling was done to collect data on behavior, foraging plants species, different parts of plants handled and consumed by Pika and association of Pika with other animals. Plants unidentified in the field were collected in herbarium sheet and submitted to the Plant Herbarium Section in Godavari. The very dried with de-structured forage plants hay-piles were considered as 'old' and freshly collected with green forage plants were considered as 'fresh' hay-piles. The moisture laden shining pellets were considered 'fresh' while dry, fungus laden structured and deformed were considered as 'old' pellets.

\section{RESULTS AND DISCUSSION}

The Royle's Pika (Ochotona roylei) were observed in two habitats in alpine talus and in Betula- Rhododendron mixed forest. They were observed grooming, feeding, calling, foraging and musing. A total of nine Royle's Pikas (7.2 individuals per hectare) in 2012 survey and ten Pikas ( 8 individuals per hectare) in 2013 survey were observed, among them nine were O. roylei (table 1). 
Table 1. The population of Pika observed in different locations of Api area.

\begin{tabular}{|c|c|c|c|c|c|}
\hline \multirow[t]{2}{*}{ SN } & \multirow[t]{2}{*}{ Location } & \multirow[t]{2}{*}{ Coordinate } & \multirow[t]{2}{*}{$\begin{array}{c}\text { Elevation } \\
\text { (m) }\end{array}$} & \multicolumn{2}{|c|}{$\begin{array}{l}\text { Number of Pika observed } \\
\text { in quadrate of each } 50 \\
\mathrm{mx} 50 \mathrm{~m}\left(2500 \mathrm{~m}^{2} \text { area) }\right.\end{array}$} \\
\hline & & & & 2012 & 2013 \\
\hline 1. & Chaulane muhan & N29 $58^{\prime} 15.0^{\prime \prime}$ E80 $56^{\prime} 06.7^{\prime \prime}$ & 3874 & 2 & 2 \\
\hline 2. & Loal meadow 1 & N29 $58^{\prime} 12.7^{\prime \prime}$ E80 $56^{\prime} 07.5^{\prime \prime}$ & 3873 & 1 & not observed \\
\hline 3. & Loal meadow 2 & N295'⒌7" E8056'11.9" & 3839 & 3 & 8 \\
\hline 4. & Loal meadow 3 & N2958'00.9" E8056'00.6" & 3827 & 2 & Fresh pellets \\
\hline 5. & Tunda & N295' $30.1^{\prime \prime}$ E80 $55^{\prime} 33.1^{\prime \prime}$ & 3738 & 1 & Fresh pellets \\
\hline 6. & Thadapan & 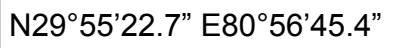 & 3522 & Not observed & Fresh pellets \\
\hline 7 & Odhar & N2954'37.3" E8057'00.3" & 3263 & Fresh pellets & Fresh pellets \\
\hline 8. & Old pellets site & N295'33.8” E8056’48.2” & 3098 & Old pellets & Old pellets \\
\hline 9. & Domaulo & N2954'12.7" E8056'43.9” & 2955 & No sign & No sign \\
\hline 10. & Simar & N295'33.4" E8056'00.7" & 2846 & No sign & No sign \\
\hline
\end{tabular}

During the 2012 survey, in the same habitat of Api Nampa area, twenty three plant species of eight families (six plants, one fern and moss) were recorded to be eaten by Pika (table 2). Plants or their parts which were eaten or taken more than 10 bites were only recorded as forage plants. In 2013 twenty five species of plants were recorded as forage plants of Pika. Rheum emodi and Aconitum ferox were two plant species added during latest observation. Among them Fragaria nubicola, Fragaria daltonia, Premula reidii, Sibbaldia cuneata, Rumex nepalansis, three species of Poaceae and moss were mostly consumed. Rosaceae family revealed the highest plant species used by Pika during that period. While Aconitum ferox is locally known as Bish, the deadly poisonous alpine plant also observed consumed by Pikas. 
J. Nat. Hist. Mus. Vol. 27, 2013

Table 2. Pika forage plant species with their consumed parts.

\begin{tabular}{|c|c|c|c|}
\hline SN & Family & Plant & Part consumed \\
\hline & Jancaceae & Jancus thomosnii & Leaf and flower \\
\hline & \multirow[t]{2}{*}{ Primulaceae } & Premula reidii & Leaf and flower \\
\hline & & Androsace lehmannii & Leaf and flower \\
\hline & \multirow[t]{7}{*}{ Rosaceae } & Potentilla microphylla & Leaf and flower \\
\hline & & Fragaria daltonia & Leaf, flower and fruit \\
\hline & & Potentilla penducularis & Leaf and flower \\
\hline & & Potentilla astrosanguinea & Leaf and flower \\
\hline & & Fragaria nubicola & Leaf, flower and fruit \\
\hline & & Potentilla spp. with red flower & Leaf and flower \\
\hline & & Potentilla curviseta & Leaf \\
\hline & \multirow[t]{6}{*}{ Ranuculaceae } & Sibbaldia cuneata & Leaf and flower \\
\hline & & Anemone tetrasepale & Leaf and flower \\
\hline & & Rannuculus adoxifol & Leaf and flower \\
\hline & & Caltha pleastris & Leaf \\
\hline & & Rannunculus hirtellus & Leaf and flower \\
\hline & & Aconitum forex (Bish) & leaf \\
\hline & \multirow[t]{2}{*}{ Polygonaceae } & Rumex nepalansis & Leaf \\
\hline & & Rheum emodi (Padam Chal) & leaf \\
\hline & Poaceae & Gahu Ghass & Leaf, flower and fruit \\
\hline & & Unknown spp. 1 & Leaf \\
\hline & & Unknown spp. 2 & Leaf \\
\hline & & Unknown spp. 3 & Leaf \\
\hline & & Allium wallichi & Leaf \\
\hline & & Fern & Leaf \\
\hline & & Moss & Whole scratch \\
\hline
\end{tabular}


The Pikas were observed consuming leaves of 25 plants species, leaves with fruit of three species and leaves along with flower of fourteen plants species. While feeding long leaves, Pikas were observed cutting at the petiole or part of leaf first and move accompanying it in mouth to some distance then stay to bigger stone and start chewing and engulfing (fig. 2). They move frequently nearby stone or under the bushes of tall grasses during travelling a bit longer distance.

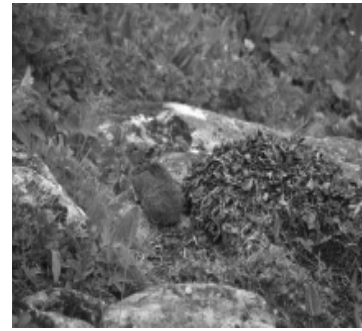

1

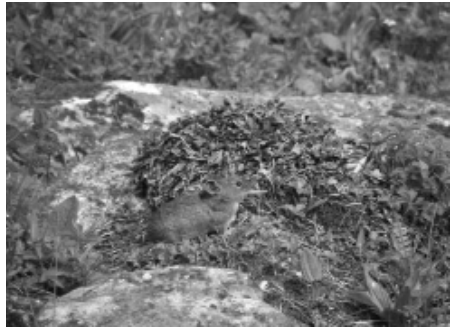

2

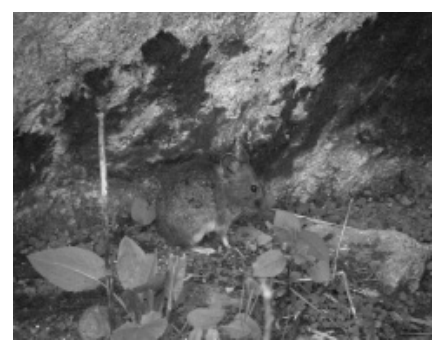

3

Figure 2. Royle's Pika foraging (1), grass leaf chewing (2) and searching leaf under stone (3).

Single old hay-pile with old pellets was observed in 2012. Hay-pile consists of five species of forage plants, Fragaria sp., Potentilla sp. and Rumex spp. and two were from Poaecae family. No haypile was recorded in 2013.

\section{Human- Pika interaction}

Api Nampa Himalaya base is one of the good destinations for Yarchagumba (Cordyceps sinensis) and other alpine herbs. People not only participate from Darchula district but from its neighboring districts Kalikot, Bhajang, Baitadi, Dadeldhura, Kailali, Bardia, Doti, Accham, Rukum and Jajarkot for herb collections. Api Nampa base is usually open from April to July for these people. Besides those people more than six herder groups with thousands of sheep and goats brought there from April to September. All of them live in temporary huts made up of plastics and wood. According to the local respondents, Pika sometime enter into their huts and steal the green vegetables, potatoes, rice, wheat and flour of grains.

People from Dui belt of Darchula (not from Lekam and Marma belt), Kalikot and other district had collected some specimens of Pika during the herb collections. Pikas were killed by throwing stone and using catapult. It was then mildly roasted over the smoky fire then kept in sun for drying. The dried Pika meat was found to carrying medicinal values. According to the experienced respondents, a small piece of Pika meat was sufficient during chilly cold time of snowing to get rid of hypothermia. It was believed to cure asthma, and cold diarrhea. They commented that it impacts dizziness immediately after consumption but after a few moment, provide physiological relaxation.

In Kedarnath Wildlife Sanctuary, Uttarakhand, West Himalaya along an altitudinal gradient from $2900 \mathrm{~m}$ to $3650 \mathrm{~m}$ amsl, Royle's Pika (Ochotona roylei) found consumed 26 plant species of 
fourteen families (Bhattacharya et al. 2009), among them only three species, Potentilla astrosanguinea, Sibbaldia cuneata and Rannunculus hirtellus were the common forage species.

Koju et al. (2012) reported 43 plants species consumed by Pika in Lantang. However, Premula reidii, Androsace lehmannii, Anemone tetrasepale, Rannuculus adoxifol, Caltha pleastris, Gahu Ghass, Allium wallichi were not reported as foraging species in Langtang. Deo et al. (2008) observed flower of Primula spp., grasses and tender moss species, while in Langtang Rumex nepalensis and grasses were observed as forage species of Pika. Change in consumption of forage plants may vary due to season, difference in plant biodiversity and location of research site. A number of taxonomically unrelated species might have similar diet and food habits. Food selection or choice is depending on plant parts, their form, component and their proportionate occurrences. The feeding species and foraging also depends on the available plant species and adaptability of animal in that particular habitat. Therefore sometime we found items, parts and even species differences in feeding ecology by the same species (Chalise 2000). Pika in Phedi of Langtang National Park consumed poisonous plants (Koju et al. 2012). Similar events and behaviour was noticed in Api Nampa also.

In Api Nampa Conservation Area, indirect signs of Pika and their pellets were observed from $3098 \mathrm{~m}$ asl. Live Pikas and burrows with fresh pellets were seen from $3263 \mathrm{~m}$ asl. Population density of observed Pika was 7.2 and 8 individual per hectare according to the study conducted in 2012 and 2013 respectively. Pika spent their maximum time in foraging, musing and feeding. They were observed feeding 23 plants species in 2012 and 25 in 2013. Pikas frequently visit the temporary huts of Yarchabumba collectors and local herders.

The global scenario reflects that wildlife products are often major sources of consumption and have high medicinal and spiritual value in many human cultures (Scoones and Pretty 1992). The use of wildlife has served multiple roles in rural communities of Nepal including spiritual, medicinal purpose, food and important contribution in livelihood (Chalise 2008, Gabji et al. 2008). Rural people use body parts of animals for curing disease of stomach, orthopedic, snake bite, eye disease and liver pain (Chalise 2010). Pikas are important, to some extent, for their fur also. In the Soviet Union prior to World War II, Pika fur was used to produce high quality pelt. Now the collection of pika skins for this purpose has ceased because of the nominal return to trappers. In Yakutia, the trapping of northern Pika continued until 1953. In some years as many as 14,000 specimens were caught (Tavrovski et al. 1971). In the Karaganda region of Kazakhstan Pikas were hunted in hundreds. This hunting has no noticeable influence on the pika populations (Sludski et al. 1980). In Api Nampa, the local people use Pika for the medicinal purposes to cure some common diseases like bodyache, joint pain and cough. Although, they use very few number that would also no impact on their population. However, scientific research on these traditional practices is needed to address the conservation issues related to Pika.

\section{ACKNOWLEDGEMENTS}

We thank all local herders, yarchgumba collectors and people from Ghusa VDC, Darchula for their cooperation, hospitality and information sharing. We are thankful to wardens of Api Nampa Conservation Area Mr. Lal Bihari Yadav, Mr SherSingh Thagunna and DNPWC for permission, facilitation, cooperation and support. Finally we are thankful to Dr. Paul Bazzard, 
Koju and Chalise : Royle's Pike (Ochotona Royle)

wildlife specialist of China Exploration and Research Society for his cooperation in field work and data collection.

\section{REFERENCES}

Abe, H., 1971. Small mammals of central Nepal. J. Fac. Agr., 56:403-406 .

Alfred, J.R.B., A.K. Das and A.K. Sanyal, 2006. Animals of India: Mammals. Zoological Survey of India.

Bhattacharya, S., B.S. Adhikari and G.S. Rawat, 2009. Abundance of Royle's Pika (Ochotona roylei) along an altitudinal gradient in Uttarakhand western Himalaya. Hystrix Italian Journal of Mammalogy, 20(2):111-119.

Chalise, M. K., 2000. Biodiversity of wild food plants in relation to the monkeys feeding ecology. In Proceeding of Eighth International Workshop of BIO-REFOR, Japan, under Biotechnology Applications for Reforestation and Bio-diversity Conservation, pp 289-294.

Chalise, M. K., 2008. Conservation and present needs. The Initiation, 2(1):212:216.

Chalise, M K., 2010. Usage of animals by the rural people in reference to Nepal. In Jha, P.K., S.B. Karmacharya,M.K. Balla, M.K. Chettri and B.B. Shrestha (eds) Sustainable Use of Biological Resources in Nepal. Ecological Society (ECOS), Kathmandu, Nepal, pp 145-151.

Chalise, M K., 2012. Report on presence and absence of Red Panda in Api Nampa Conservation Area, Darchula, Nepal, 14 p.

Deo, R.K., H.K. Shrestha, B. Khanal and S. Devkota, 2008. A study vernerability assessment and formulation of climate change adaptation strategies for Langtang National Park and Buffer Zone, Socio-economic, Agro-Forestry and Environment (SAFE), Kathmandu, Nepal.

Gibji, N.T.T, T. Hui and D. Oyl, 2008. Adi tribes of Mirem VIllage, Arunachal Pradesh. The Initiation, 2(1):183-198

Hoffmann, R.S. and A.T. Smith, 2005. Lagomorphs. In Wilson, D.E. and D. M. Reeder (eds) Mammal Species of the World. Johns Hopkins University Press, pp 185-211 (3rd edition).

Holtcamp, W., 2010. Silence of the Pikas. Bio Science, 60(1):8-12.

Kawamichi, T.,1968. Winter behaviour of the Himalayan Pika. (Ochotona roylei). Journal of the faculty of Science, Hokkaido Univ. Ser. VI .Zool.,16:582-594.

Kawamichi, T., 1971. Daily activities and social pattern of two Himalayan pikas, Ochotona marcrotis and Ochotona roylei, observed at Mt. Everest. J. Fac. Sci. Hokkaido University, Japan, ser VI, Zool.,17:587-609.

Khanal, B. 2007. New report on the symbiotic relation of Ochotona roylei and scaly breasted wren babbler at Ganesh Himalayan area of central Nepal. Our Nature, 5:37-40.

Koju, N.P. and M.K. Chalise, 2012. A survey on Royle's Pika (Ochotona roylei) at Api Nampa Conservation Area, far western Himalaya, Darchula, Nepal. The Initiation, Vol 5 (in press). Koju, N.P. and M.K. Chalise, 2013. Pika of Api Nampa, Hamro Sampada, 1:13 (in press). 
Koju, N.P., M.K. Chalise and R.C. Kyes, 2012. Seasonal survey of Large Eared Pika (Ochotona macrotis) at Langtang Natonal Park, Nepal. University Grant Commission Journal,1:74-82. Koju, N.P, M.K. Chalise and R.C. Kyes , 2013. Ecology of Pika (Ochotona spp.) in Gosainkunda area, Langtang National Park, Nepal. In Khanna, D. R., G. S. Solanki and S. K. Pathak (eds) Environment, Biodiversity and Traditional System. Biotech Books, India, pp 75-86.

Naumov, R.L., 1974. Ecology of Ochotona alpina in the west Sayan. Zool. Zh., 53:1524-1529 Prater, S.H., 2005. Book of Indian Animals. Bombay Natural History Society, Hornbill House Bombay, India, 3rd edition.

Primack, R. B., 1998. Essential of Conservation Biology. Sinauer, Massachusetts, USA, (2nd edition).

Scoones, I.M. and J. Pretty, 1992. The Hidden Harvest, Wild Foods and Agricultural System: A Literature Review and Annotated Bibliography. HED, SIDA and WWF, London, UK and Gland Switzerland

Shrestha, T.K., 1997. Mammals of Nepal. TU Curriculum Center, Kathmandu, pp 248-256.

Sludski, A. A., A. D. Bernstein, I.G. Shubin, V.A. Fadeev, G.I. Orlov, A. Bekenov, V.I. Karitonov and S.R. Utinov, 1980. Mammals of Kazakhstan. Vol. 2:Lagomorpha. "Nauka," Kazakh SSR, Alma-Ata, $236 \mathrm{p}$.

Smith, A. T., and Y. Xie, 2008. The Mammals of China. Princeton University Press, Princeton, New Jersey, USA.

Smith, A.T., N. Formozov, R.S. Hoffmann, Z. Changlin and M.A. Erbajena, 1990. The Pika accounts of genera and species, rabbits, hares and pikas. Status Survey and Conservation Action Plan. Chapter 3, IUCN, Gland, Switzerland.

Smith, A.T.,1974. Distribution and dispersal of Pikas: influences of behaviour and climate. Ecology, 55:1368-1376.

Tavrovski,V.A., O.V. Yegorov, V.G. Krivosheyev, M.V. Popov and Y.U, Labutin, 1971. Mammals of Yakutia. "Nauka," Moscow-Leningrad, 659 p.

\section{AUTHOR'S ADDRESS}

Narayan P. Koju' ${ }^{\mathbf{1}}$

Khwopa College, Bhaktapur, Nepal

Mukesh Kumar Chalise ${ }^{2}$

Central Department of Zoology, Tribhuvan University, Kirtipur, Kathmandu, Nepal 